\title{
技術報告
}

\section{動特性解析コードを用いた高温ガス炉に接続する 水素製造システムの評価}

\author{
佐藤 博之 ${ }^{1, *}$, 大橋 弘史 $^{1}$, 稲葉 良知 $^{1}$, \\ 西原 哲夫 ${ }^{1}$, 林 光二 $^{1}$, 稲垣 嘉之 $^{1}$
}

Evaluation of Hydrogen Production System Coupling with HTTR Using Dynamic Analysis Code

\author{
Hiroyuki SATO ${ }^{1 *}$, Hirofumi OHASHI ${ }^{1}$, Yoshitomo INABA ${ }^{1}$, \\ Tetsuo NISHIHARA ${ }^{1}$, Koji HAYASHI ${ }^{1}$ and Yoshiyuki INAGAKI ${ }^{1}$ \\ 1Japan Atomic Energy Agency, 4002 Narita-cho, Oarai-machi, Higashi-ibaraki-gun, Ibaraki 311-1393, Japan \\ (Received March 29, 2006 and accepted in revised form July 13, 2006)
}

\begin{abstract}
The Japan Atomic Energy Agency (JAEA) was entrusted "Development of Nuclear Heat Utilization Technology" by Ministry of Education, Culture, Sports, Science and Technology. In this development, the JAEA investigated the system integration technology to couple the hydrogen production system by steam reforming with the High Temperature Engineering Test Reactor (HTTR). Prior to the construction of the hydrogen production system coupling with the HTTR, a dynamic analysis code had to be developed to evaluate the system transient behaviour of the hydrogen production system because there are no examples of chemical facilities coupled with nuclear reactor in the world. This report describes the evaluation of the hydrogen production system coupling with HTTR using analysis code, N-HYPAC, which can estimate transient behaviour of the hydrogen production system by steam reforming. The results of this investigation provide that the influence of the thermal disturbance caused by the hydrogen production system on the HTTR can be estimated well.
\end{abstract}

KEYWORDS: nuclear heat utilization technology, system integration technology, steam reforming, HTTR, hydrogen production system, dynamic analysis code, transient behaviour, $N$-HYPAC, thermal disturbance

\section{I. 緒 言}

高温ガス炬は，冷却材にへリウムガス，主要構造材並び に減速材に黑鉛を用いることにより，1,000 $\mathrm{C}$ 近い原子炉 出口冷却材温度を達成することができるため，発電のほ か，水素製造，化学工業の熱源等，多用途にわたる利用が 可能上なる。特に水素は，近年の燃料電池自動車の実用化 に向けての開発研究の高まりに見られるように，近い将来 に扔いて需要の急増が予想される。しかし，自然界に抢い て単独で存在する水素はごく少量であり，ほとんどが水や 化石然料等の化合物の状態で存在していることから，水素 製造には発電と同様に，エネルギーを必要とする。したが って，将来予想される水素需要に対しては，水素製造に必 要な大量のエネルギーを環境への負荷をかけずに供給する ことが重要課題となる。高温ガス炉を水素製造の熱源とす る水素製造システムは化石燃料を使わないことから， $\mathrm{CO}_{2}$ の排出が少ないため, 将来の水素製造システムとして有望 である。

日本原子力研究開発機構 (以下,「原子力機構」と呼ぶ)

1 日本原子力研究開発機構

* Corresponding author, E-mail: sato.hiroyuki09@jaea.go.jp

(C)Atomic Energy Society of Japan
では，将来の水素利用社会への貢献を目指して高温ガス炉 水素製造システムの研究開発を進めている1)。国内唯一の 高温ガス炉である高温工学試験研究炉 HTTR (High Temperature Engineering Test Reactor)では, 2004年 4 月に 世界で初めて原子炉出口冷却材温度 $950^{\circ} \mathrm{C}$ 核熱を炬外に 取り出すことに成功しており2)，HTTRに水素製造設備を 接続した実証試験を計画している。原子力機構は文部科学 省より平成 8 年度から平成 17 年度にかけて HTTR と天然 ガスの水蒸気改質法による水素製造設備との接続について 技術開発を行った。熱利用系として水素製造設備等のよう な化学プラントを原子炬に接続したことは世界的に例がな いため，HTTR と水素製造設備の接続に当たって，ヘリ ウムガス抢よび水素製造設備の過渡挙動を評価するための 動特性解析コードが必要であった。原子力機構では， HTTR と水蒸気改質法による水素製造設備とを接続した システム(以下，「水素製造システム」と呼ぶ)において， 水素製造設備に起因する熱過渡を抑制するために蒸気発生 器一放熱器を用いた冷却システムを提案しており，動特性 コード開発においては，この冷却システムでの沸騰・凝縮 を含む蒸気/水の二相流の熱流動計算および水蒸気改質器 での化学反応計算を可能とすることが課題であった。その ため，新たに動特性解析コードを開発し，N-HYPAC ${ }^{31}$ 
(Nuclear Hydrogen Production Analysis Code) と名付け た。をた，水素製造システムの模擬試験装置(以下，「試験 装置」と呼ぶ)を完成させ4)，本装置の定常時および非定 常時の試験結果を用いて, 本解析コードの解析結果と試験 結果の比較を行った。

本報では，本解析コードの概要，解析結果と試験結果の 比較および水素製造システムの解析結果について述べる。

\section{II. 水素製造システムの概要}

水素製造システムの系統図を Fig. 1 に示す。水素製造 システムは原子炉，中間熱交換器，水素製造設備から構成 され，原子炉と中間熱交換器の間を 1 次ヘリウムガス, 中間熱交換器と水素製造設備との間を 2 次へリウムガス が循環している。原子炉で $950^{\circ} \mathrm{C} に$ 加熱された 1 次へリウ ムガスは, 中間熱交換器で 2 次へリウムガスと熱交換し (熱交換量 $10 \mathrm{MW}$ )，2 次ヘリウムガスは水素製造設備の 水蒸気改質器等の熱源として供給される。水素製造設備は （1）式に示す水蒸気改質反応により，原料ガス(天然ガ ス）と水蒸気を反応させて水素を製造する。

$$
\mathrm{CH}_{4}+\mathrm{H}_{2} \mathrm{O}=3 \mathrm{H}_{2}+\mathrm{CO}+\Delta H(298 \mathrm{~K}) ;
$$$$
\Delta H(298 \mathrm{~K})=206 \mathrm{~kJ} / \mathrm{mol}
$$

水蒸気改質器には水蒸気改質反応を行わせるため，触媒 を充填した反応管が設置されており，反応管の外側を 2 次へリウムガス (圧力 : $4.1 \mathrm{MPa}$, 水蒸気改質器入口温 度 : $880^{\circ} \mathrm{C}$ ), 内側をプロセスガス(メタンと水蒸気の混合 ガス並びに反応後の生成ガスの総称, 圧力 : $4.5 \mathrm{MPa}$, 水 蒸気改質器入口温度 : $450^{\circ} \mathrm{C}$ ) が流れて熱交換を行う。水 素製造システムの主要諸元を Table 1 に示す。また，水 素製造システムでは HTTRのスクラムを防止する観点か ら，2次ヘリウムガスの温度変動を $\pm 10^{\circ} \mathrm{C}$ 以内に制御する ことを目標としている5)。そこで, 水蒸気改質器の負荷変
動による原子炬への戻りヘリウムガスの熱過渡変化を抑制 するため, 水蒸気改質器の下流に蒸気発生器之放熱器を設 置し, 蒸気発生器の保有水の潜熱により 2 次へリウム力 スの熱過渡を吸収する冷却システムを採用している。

\section{III. 動特性解析コードの概要}

\section{1. 動特性解析コードの特長}

水素製造システムの蒸気発生器一放熱器を用いた冷却シ ステムを取り扱う動特性解析コードとして，RELAP5の ように蒸気/水の二相流の熱流動計算が可能であるコード があるが, 水蒸気改質器での化学反応計算を行うことはで きない。また，化学プラントの解析コードにおいては，蒸

Table 1 Design specifications of mock-up test facility and HTTR hydrogen production system by steam reforming of methane

\begin{tabular}{lcc}
\hline \multicolumn{1}{c}{ Items } & $\begin{array}{c}\text { HTTR hydrogen } \\
\text { production } \\
\text { system }\end{array}$ & $\begin{array}{c}\text { Mock-up test } \\
\text { facility }\end{array}$ \\
\hline $\begin{array}{l}\text { Pressure } \\
\text { (process-gas/helium-gas) } \\
\text { Temperature at inlet of }\end{array}$ & $4.5 / 4.1 \mathrm{MPa}$ \\
$\begin{array}{l}\text { steam reformer } \\
\text { (process-gas/helium-gas) }\end{array}$ & $450 / 880^{\circ} \mathrm{C}$ \\
$\begin{array}{l}\text { Temperature at outlet of } \\
\text { steam reformer } \\
\text { (process-gas/helium-gas) }\end{array}$ & $580 / 585^{\circ} \mathrm{C}$ & $600 / 650^{\circ} \mathrm{C}$ \\
$\begin{array}{l}\text { Methane (natural gas) } \\
\text { feed }\end{array}$ & $0.3889 \mathrm{~kg} / \mathrm{s}$ & $0.012 \mathrm{~kg} / \mathrm{s}$ \\
$\begin{array}{l}\text { Helium gas circulation } \\
\text { Mole ratio of steam to car- } \\
\text { bon (S/C) }\end{array}$ & $2.519 \mathrm{~kg} / \mathrm{s}$ & $0.091 \mathrm{~kg} / \mathrm{s}$ \\
$\begin{array}{l}\text { Hydrogen production } \\
\text { ability }\end{array}$ & $4,240 \mathrm{~m}^{3} / \mathrm{h}$ & $110 \mathrm{~m}^{3} / \mathrm{h}$ \\
$\begin{array}{l}\text { Heat source } \\
\text { Reactor }\end{array}$ & $\begin{array}{c}\text { Electric heater } \\
(0.42 \mathrm{MW})\end{array}$ \\
\hline
\end{tabular}

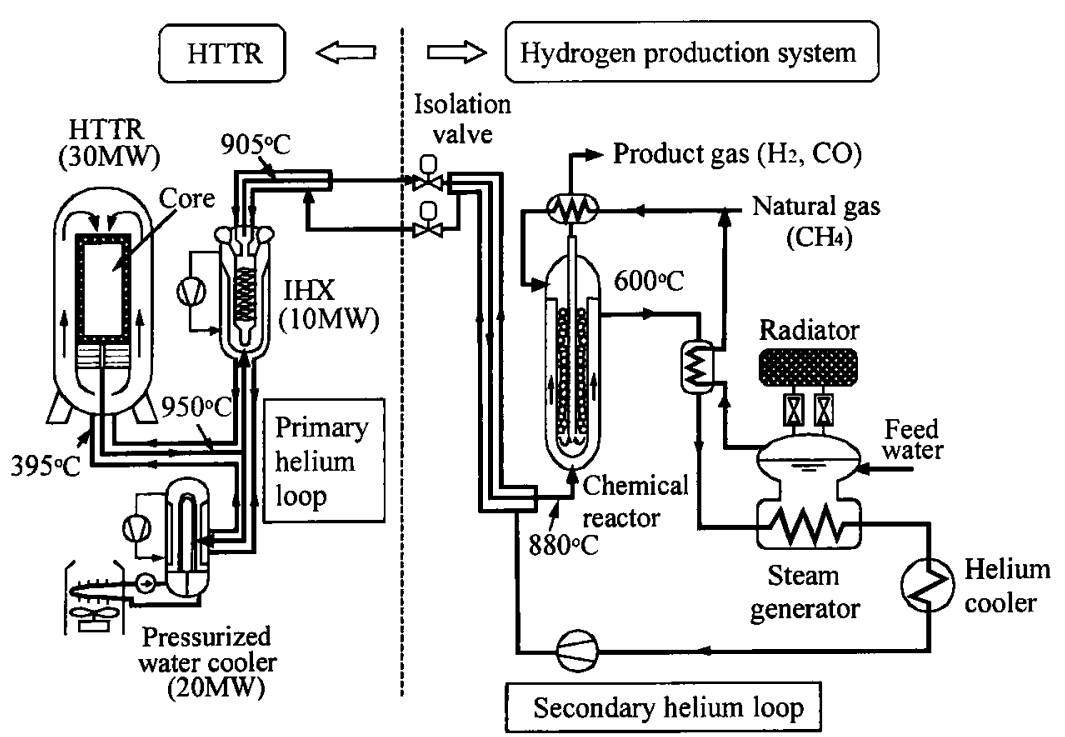

Fig. 1 Conceptual flow diagram of HTTR hydrogen production system by steam reforming of methane 
気発生器一放熱器を用いた冷却システムでの自然循環時の 挙動の解析が可能であるコードはない。このように，原子 炬に化学プラントを接続した新しい原子炉システムの動特 性を評価できる解析コードは存在しない。N-HYPACで は，水素製造システムでの原子师本体を除く，1次へリウ ムガス系，2次へリウムガス系および水素製造設備を構成 する機器・配管，升抢よび制御系を対象とし，その温度， 圧力, 流量およよ゙制御特性等の動特性が計算できる。ま た，使用流体として，天然ガス，窒素ガス，生成ガス(水 素, 二酸化炭素, 一酸化炭素), 水, 水蒸気 (二相流を含 む)およびへリウムガスを取り扱うことができる。なお， 詳細については参考文献3.6)を参照されたい。

\section{2. 解析モデルの概要}

（1）ヘリウム系、プロセスガス系解析モデル

N-HYPAC の開発において，水素製造システムの化学 反応器である水蒸気改質器での化学反応計算, ヘリウムガ ス系抢よびブロセスガス系の各熱交換器, 配管での熱流動 計算を行う解析モデルを開発した。以下に，その概要を述 ベる。

\section{(a) 配管}

配管は，流体の熱流動計算を 1 次元でモデル化し，基 礎式には質量，運動量掞よびエネルギーの各保存式，気体 の状態方程式を用いた。また，伝熱については 1 次元で 取り扱った。

\section{(b) 水蒸気改質器}

水蒸気改質器の解析モデル概要図を Fig. 2 に示す。水 蒸気改質器では, 質量保存式およびエネルギ一保存式を基 礎式として熱収支式と物質収支式を解くことにより，水蒸 気改質器内の温度分布, 濃度分布を算出した。水蒸気改質 器はヘリウムガスとプロセスガスとの熱交換のほか, プロ
セスガスの再生熱交換を行うバイヨネット型であるため, 伝熱モデルに関しては 2 次元とし，触媒層内のプロセス ガス，内管内の生成ガス，ヘリウムガス相互の管壁を介し たモデルとした。また，流れに関しては 1 次元として扱 った。触媒層内の化学反応計算には定数型反応速度式を用 い, 反応速度定数は一般的なアレニウス型の式で記述し た。（2）から（4) 式に主要な反応である水蒸気改質反応 およびシフト反応の反応速度式を示す。

$$
\begin{aligned}
& r_{1}=k_{1} \cdot\left(P_{\mathrm{CH}_{4}} \cdot P_{\mathrm{H}_{2} \mathrm{O}}-\frac{P_{\mathrm{CO}} \cdot P_{\mathrm{H}_{2}}{ }^{3}}{K_{P, 1}}\right) \quad \text { (水蒸気改質反心式) } \\
& r_{2}=k_{2} \cdot\left(P_{\mathrm{CO}} \cdot P_{\mathrm{H}_{2} \mathrm{O}}-\frac{P_{\mathrm{CO}_{2}} \cdot P_{\mathrm{H}_{2}}}{K_{P, 2}}\right) \quad \text { （シフト反応式） } \\
& k=k_{0} \cdot \exp \left(\frac{-E}{R \cdot T}\right)
\end{aligned}
$$

ここで， $r$ ：触媒重量あたりの反応速度 $(\mathrm{mol} / \mathrm{s} / \mathrm{kg}-\mathrm{cat})$

$k$ : 反応速度定数 $\left(\mathrm{mol} / \mathrm{s} / \mathrm{kg}-\mathrm{cat} / \mathrm{Pa}^{2}\right)$

$P_{i}: i$ 成分の分圧 $(\mathrm{Pa})$

$K_{P}$ : 圧平衡定数 $\left(\mathrm{Pa}^{*}\right)$

（*：水蒸気改質反応では 2 , シフト反応では 0$)$

$k_{0}:$ 頻度因子 $\left(\mathrm{mol} / \mathrm{s} / \mathrm{kg}-\mathrm{cat} / \mathrm{Pa}^{2}\right)$

$E ：$ 活性化エネルギー $(\mathrm{J} / \mathrm{mol})$ を表す。

また，原料となる天然ガスには数種類の低級炭化水素を含 んでいるため，これらの熱分解反応を考慮した。本解析 コードで使用した化学反応式および反応速度式を Table 2 に示す。

化学反応は触媒層内のプロセスガスのみに対して考虑 し，（5)式に示す物質収支式を用いた。

$$
\frac{d G}{d z}=\left(\rho_{c} \cdot A\right) \Sigma v \cdot r
$$

ここで， $G_{i}: i$ 成分の物質量流量 $(\mathrm{mol} / \mathrm{s})$,

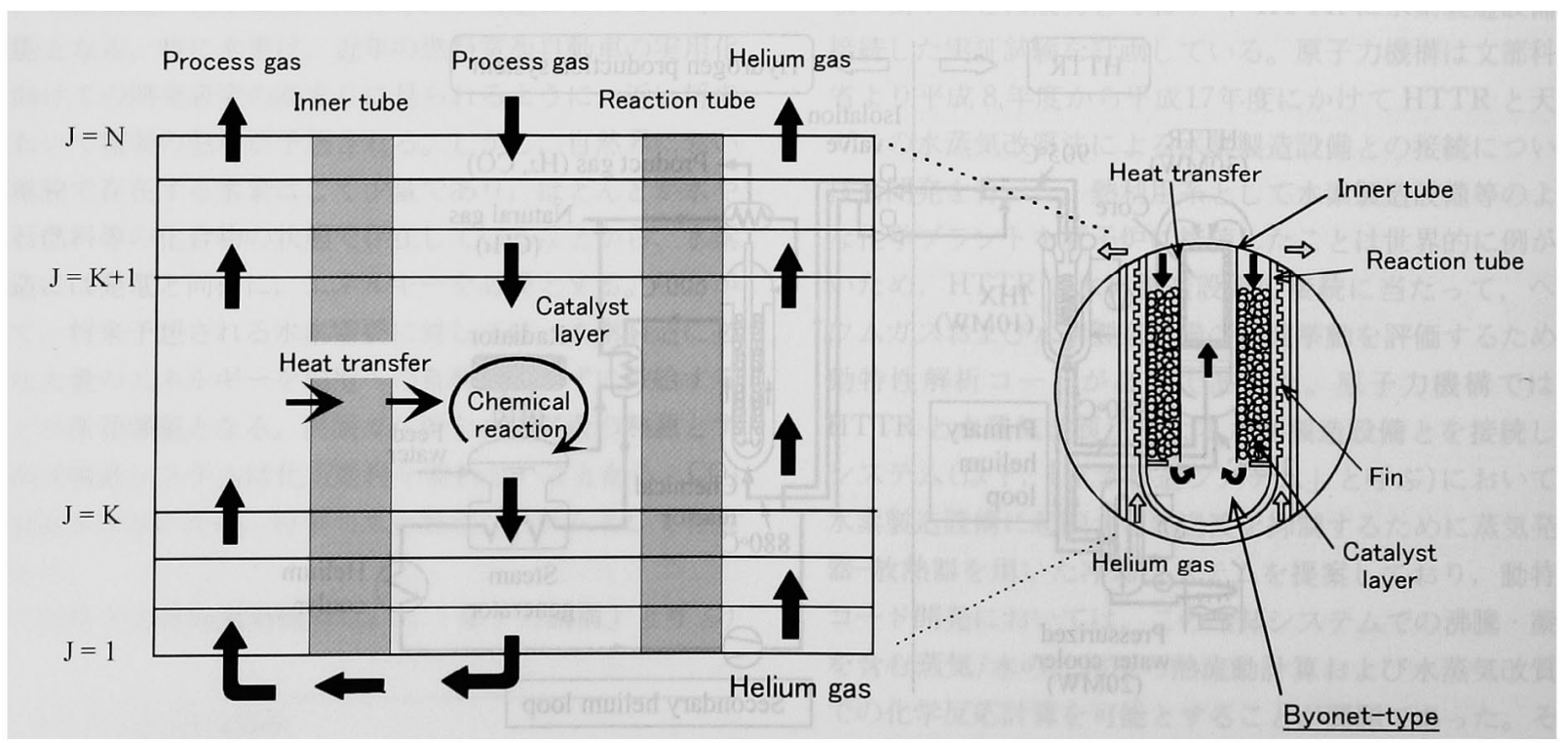

Fig. 2 Numerical analysis model of the steam reformer 
Table 2 Chemical equations and reaction rate equations using in the analytical model of the steam reformer

\begin{tabular}{|c|c|}
\hline Chemical equation & Reaction rate equation \\
\hline $\mathrm{CH}_{4}+\mathrm{H}_{2} \mathrm{O}=3 \mathrm{H}_{2}+\mathrm{CO}$ & $\begin{array}{l}k_{0,1} \exp \left(-E_{1} / R T\right) \\
\left(P_{\mathrm{CH}_{4}} P_{\mathrm{H}_{2} \mathrm{O}}-P_{\mathrm{CO}} P_{\mathrm{H}_{2}}{ }^{3} / K_{\mathrm{P}, 1}\right)\end{array}$ \\
\hline $\mathrm{CO}+\mathrm{H}_{2} \mathrm{O}=\mathrm{H}_{2}+\mathrm{CO}_{2}$ & $\begin{array}{l}k_{0,2} \exp \left(-E_{2} / R T\right) \\
\left(P_{\mathrm{CO}} P_{\mathrm{H}_{2} \mathrm{O}}-P_{\mathrm{CO}_{2}} P_{\mathrm{H}_{2}} / K_{\mathrm{P}_{2}, 2}\right)\end{array}$ \\
\hline $\mathrm{C}_{4} \mathrm{H}_{10}=\mathrm{C}_{4} \mathrm{H}_{8}+\mathrm{H}_{2}$ & $\left.k_{0,3} \exp \left(-E_{3} / R T\right) P_{\mathrm{C}_{4} \mathrm{H}_{10}}\right)$ \\
\hline $\mathrm{C}_{4} \mathrm{H}_{10}=\mathrm{C}_{2} \mathrm{H}_{6}+\mathrm{C}_{2} \mathrm{H}_{4}$ & $\left.k_{0,4} \exp \left(-E_{4} / R T\right) P_{\mathrm{C}_{4} \mathrm{H}_{10}}\right)$ \\
\hline $\mathrm{C}_{4} \mathrm{H}_{10}=\mathrm{C}_{3} \mathrm{H}_{6}+\mathrm{CH}_{4}$ & $\left.k_{0,5} \exp \left(-E_{5} / R T\right) P_{\mathrm{C}_{4} \mathrm{H}_{10}}\right)$ \\
\hline $\mathrm{C}_{4} \mathrm{H}_{8}+\mathrm{H}_{2}=\mathrm{C}_{2} \mathrm{H}_{6}+\mathrm{C}_{2} \mathrm{H}_{4}$ & $\left.k_{0,6} \exp \left(-E_{6} / R T\right) P_{\mathrm{C}_{4} \mathrm{H}_{8}}\right)$ \\
\hline $\mathrm{C}_{3} \mathrm{H}_{8}=\mathrm{C}_{2} \mathrm{H}_{4}+\mathrm{CH}_{4}$ & $\left.k_{0,7} \exp \left(-E_{7} / R T\right) P_{\mathrm{C}_{3} \mathrm{H}_{8}}\right)$ \\
\hline $\mathrm{C}_{3} \mathrm{H}_{8}=\mathrm{C}_{3} \mathrm{H}_{6}+\mathrm{H}_{2}$ & $\left.k_{0,8} \exp \left(-E_{8} / R T\right) P_{\mathrm{C}_{3} \mathrm{H}_{\mathrm{a}}}\right)$ \\
\hline $\mathrm{C}_{3} \mathrm{H}_{8}=\mathrm{C}_{2} \mathrm{H}_{6}+0.5 \mathrm{C}_{2} \mathrm{H}_{4}$ & $\left.k_{0,9} \exp \left(-E_{9} / R T\right) P_{\mathrm{C}_{3} \mathrm{H}_{8}}\right)$ \\
\hline $\mathrm{C}_{3} \mathrm{H}_{6}+\mathrm{H}_{2}=\mathrm{C}_{2} \mathrm{H}_{4}+\mathrm{CH}_{4}$ & $\left.k_{0,10} \exp \left(-E_{10} / R T\right) P_{\mathrm{C}_{3} \mathrm{H}_{6}} P_{\mathrm{H}_{2}}\right)$ \\
\hline $\mathrm{C}_{2} \mathrm{H}_{6}+\mathrm{H}_{2}=2 \mathrm{CH}_{4}$ & $\left.k_{0,11} \exp \left(-E_{11} / R T\right) P_{\mathrm{C}_{2} \mathrm{H}_{6}} P_{\mathrm{H}_{2}}\right)$ \\
\hline $\mathrm{C}_{2} \mathrm{H}_{4}+\mathrm{H}_{2}=\mathrm{C}_{2} \mathrm{H}_{6}$ & $\left.k_{0,12} \exp \left(-E_{12} / R T\right) P_{\mathrm{C}_{2} \mathrm{H}_{1}} P_{\mathrm{H}_{2}}\right)$ \\
\hline
\end{tabular}

$\rho_{c}:$ 触媒充填密度 $\left(\mathrm{kg}-\mathrm{cat} / \mathrm{m}^{3}\right)$,

$A$ : 流路断面積 $\left(\mathrm{m}^{2}\right)$,

$v$ : 反応式におうりる化学量論係数を表す。

水蒸気改質器内の熱伝達係式は, 生成ガスと内管間およ びへリウムガスとガイド管間については（6)式に示す Kays の式，触媒層内のプロセスガスと内管扩よび反応管 間については (7), (8)式に示す矢木·国井の式, へリウ ムガスと反応管間については (9)式に示す Knudsen の式 を用いた。

$$
\begin{aligned}
& N u=0.022 \operatorname{Re}^{0.8} \operatorname{Pr}^{0.5} \\
& N u=\left(D_{p} / D_{t}\right) \cdot\left(\lambda_{e} / \lambda_{g}\right) \cdot(a+\Phi / y) \\
& y=4\left(D_{p} / D_{t}\right) \cdot\left(L / D_{t}\right) \cdot\left(\lambda_{e} / \lambda_{g}\right) \cdot\left(P_{r} \cdot R_{\varepsilon}\right) \\
& N u=0.039 \cdot \operatorname{Re}^{0.87} \cdot \operatorname{Pr}^{0.4} \cdot\left(\frac{S_{p}}{D}\right)^{0.4} \cdot\left(\frac{H_{f}}{D}\right)^{-0.19}
\end{aligned}
$$

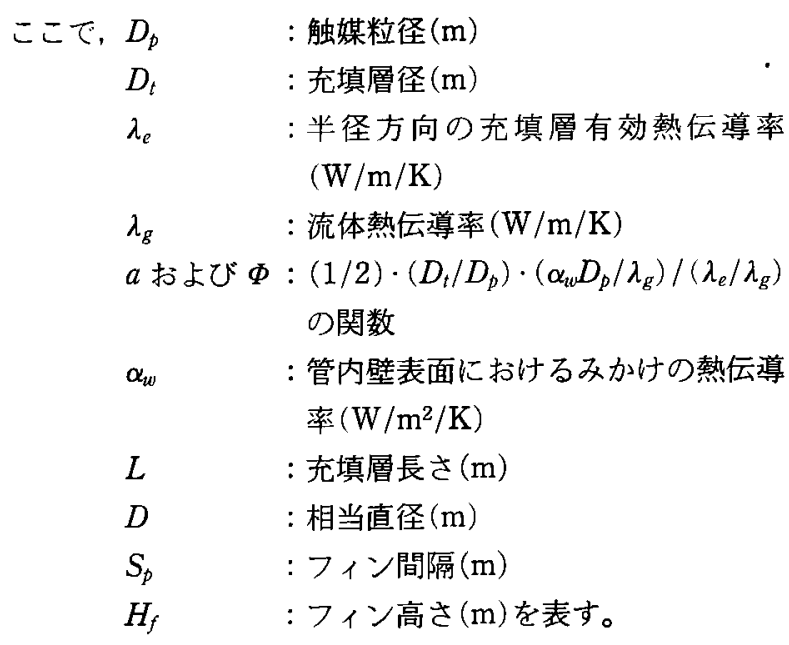

また，圧力損失の推算式は，生成ガス流路については (10)式に示す Blasius の式，触媒層内については(11)式に 示す Burke-Plummer の式，ヘリウムガス流路については (12)式に示す Knudsenの式を用いた。

$$
\begin{aligned}
& \Delta P=f \cdot \frac{L}{D} \cdot \frac{\rho \cdot u^{2}}{2}, f=\frac{0.3164}{R e^{1 / 4}} \\
& \Delta P=f \cdot \frac{L_{p}}{d_{P}} \cdot \frac{\rho \cdot u_{0}^{2}}{2 g_{c}} \cdot \frac{(1-\varepsilon)}{\varepsilon^{3}}, f=150 \frac{(1-\varepsilon)}{R e_{p}}+1.75 \\
& \Delta P=4 f \cdot \frac{G^{2}}{2 g_{c} \cdot \rho} \cdot \frac{L}{D} \cdot\left(\frac{\mu w}{\mu}\right)^{0.14} \\
& \Xi こ て ゙,: \text { 管長 }(\mathrm{m}) \\
& D: \text { 相当径 }(\mathrm{m}) \\
& u: \text { 線速度 }(\mathrm{m} / \mathrm{s}) \\
& L_{P}: \text { 充填層高さ }(\mathrm{m}) \\
& d_{p}: \text { 相当粒子径 }(\mathrm{m}) \\
& u_{0}: \text { 層内みかけ線速度 }(\mathrm{m} / \mathrm{s}) \\
& g_{c}: \text { 重力加速度 }\left(\mathrm{m} / \mathrm{s}^{2}\right) \\
& \varepsilon: \text { 層内空隙率 } \\
& R e_{p}: \text { 粒子レイノルズ数 } \\
& G: \text { 質量速度 }\left(\mathrm{kg} / \mathrm{m}^{2} / \mathrm{s}\right) \\
& \mu_{w}: \text { 管壁温度における㧧体の粘度 }(\mathrm{kg} / \mathrm{m} / \mathrm{s}) \\
& \mu: \text { 流体の粘度 }(\mathrm{kg} / \mathrm{m} / \mathrm{s}) \text { を表す。 }
\end{aligned}
$$

(c) 原料ガス過熱器, 原料ガス加熱器

原料ガス過熱器はブロセスガスと生成ガスの熱交換を行 う機器であり，U字型二重管式の熱交換器である。解析 モデルではプロセスガス抢よび生成ガスの流路をそれぞ れ, 直管としてモデル化した。内側の円管流路であるプロ セスガス流路の熱伝達係数の推算式には Dittus-Boelter の 式 $\left(N u=0.023 R e^{0.8} P^{0.4}\right)$, 外側の環状流路である生成がス 流路の熱伝達係数の推算式には環状流路の平滑管の伝熱式 である Wiegant の式? $\left(N u=0.023 \operatorname{Re}^{0.8} \mathrm{Pr}^{0.4}\left(D_{2} / D_{1}\right)^{0.45}\right)$ を 用いた。

$$
\begin{aligned}
\text { ここで, } & D_{1}: \text { 内管外佳 }(\mathrm{m}) \\
& D_{2}: \text { 外管内径 }(\mathrm{m}) \text { を表す。 }
\end{aligned}
$$

\section{（2）水蒸気系解析モデル}

水素製造システムの蒸気発生器, 放熱器および蒸気過熱 器の解析モデル概要図を Fig. 3 に示す。蒸気発生器, 放 熱器, 蒸気過熱器の解析には沸騰・凝縮計算を行うことが 可能である RELAP5 を使用した。蒸気発生器のヘリウム ガス側および放熱器の空気側の伝熱流動計算については, 今回使用したRELAP5/MOD2 では単相の非凝縮ガスに より満たされたボリュームについて計算を行うことができ ないため, 新規にモジュールを開発し, RELAP5に追加 した。RELAP5はノードジャンクション法を用いた解析 コードであり，基礎式は気液各相の連続の式，各相の運動 量の式，各相のエネルギー式で構成される。また，蒸気発 生器の伝熱管等の固体境界を表す要素である Heat structure $^{6)}$ を用いることにより，気液を内包するボリュー ムとの間を移動する熱量を計算できる。流体とエネルギー は, 1 次元のモデルで近似され, 流路, 体積, 流路断面積 等で構成される物理的なシステムは，ジャンクションでつ ながれたコントロールボリュームのネットワークを構成す $ろ^{6)}$ 。 


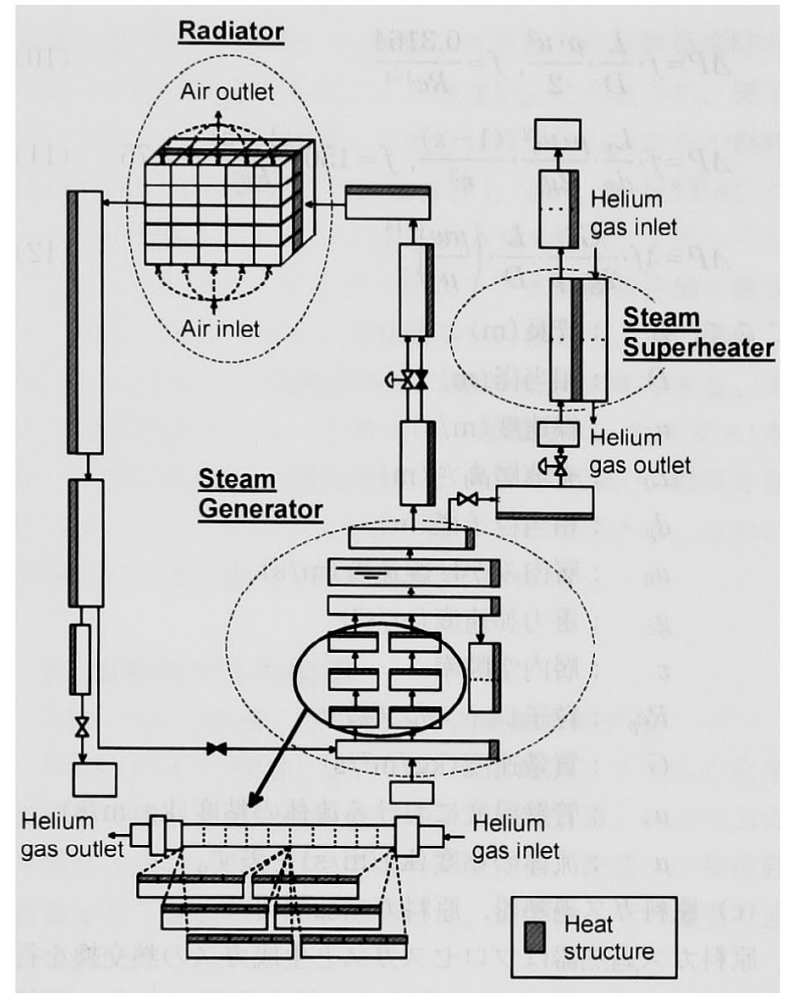

Fig. 3 Nodalization scheme of the cooling system for the helium gas with steam generator and radiator of mock-up test facility including steam superheater

\section{(a) 蒸気発生器}

蒸気発生器は横置き直管式ケトル型蒸気発生器である。 本解析モデルでは大きく分けて上部ブレナム部, 伝熱管 部，下降流領域，下部プレナム部に分割した。上部ブレナ 么部は気液分離と再循環流れの観点加気相領域, 気夜境 界領域，液相領域に 3 分割した。また，蒸気発生器の液 面が各解析セルの境界を通過すると数值計算上の圧力振動 や流量振動を生じる恐れがあるため, 気液境界領域の高さ は液面が上下した場合でも液面が気液境界領域内に収まる ような高さとした。蒸気発生器液相の水平方向の温度分布 は比較的小さいと考えられるが，ヘリウムガスの温度分布 を考虑し，伝熱管水側は高温部と低温部として水平方向 2 分割とした。また，垂直方向には水の温度分布および熱伝 達率の分布を考慮し 3 分割とした。伝熱管へリウムガス 側(新規モシュュール)は27本の伝熱管内の流れを1チャン ネルでモデル化した。へリウムガスの出入口温度差は非常 に大きいため，温度分布を考慮し，1チャンネルをへリウ ムガスの流れ方向に10分割した。伝熱管水側の熱伝達式 は RELAP5 で用意されている熱伝達パッケージを使用し た。また，ヘリウムガス側の熱伝達式は Dittus-Boelter の 式を使用した。

(b) 放熱器

放熱器の伝熱管部の管内水と管外空気はクロスフロー流 れになる。空気側の流路は入口と出口の温度差が大きいた
め, 各チャンネルを空気の流れ方向 (垂直方向)に 5 分割 した。また，水側の流路については分割数を多くした場 合, 蒸気の凝縮が分割メッシュ境界上で生じ，数值解析上 不安定な計算となることがあるため，数值解析的に安定し た定常状態が得られる分割数をサーベイし，5分割とし た。放熱器伝熱管水側の熱伝達式は RELAP5 で用意され ている熱伝達パッケージを使用し，伝熱管空気側(新規モ ジュール)の熱伝達式は設計式である Jameson の式) $(N u$ $\left.=0.092 \operatorname{Re}^{0.723} \mathrm{Pr}^{0.333}\right)$ を使用した。

\section{(c) 蒸気過熱器}

蒸気過熱器は U 字型 2 重管式の熱交換器であるが, 簡 易的に対向流形の熱交換器を採用し，それぞれ直管の流路 を2 分割し，熱構造材モデルによりモデル化した伝熱管 を介して熱交換を行うモデルとした。蒸気過熱器水側の熱 伝達式は RELAP5 で用意されている熱伝達パッケージを 使用し、ヘリウムガス側の熱伝達式は Dittus-Boelter の式 を使用した。

\section{IV. 動特性解析コード解析結果と 試験結果の比較}

試験装置の試駼結果のうち，定常状態である定格運転時 および非定常状態である化学反応停止時の試験結果を用い て解析を行った。以下に試験装置, 化学反応停止試験の概 要および解析結果と試駼結果の比較について述べる。

\section{1. 試験装置 ${ }^{9}$ の概要}

試験装置は，水素製造システムの中間熱交換器から下流 の 2 次へリウムガス采および水素製造設備を模擬したも のであり, 中間熱交換器の代わりに電気ヒータ $(0.38$ MW)を用いている。Table 1 に水素製造システムと試験 装置の主要諸元を示す。へリウムガスやブロセスガスの流 量については, 水蒸気改質器の反応管内外の熱伝墶特性, 庄力損失特性抢よび氷蒸気改質反応特性を明らかにする上 で必要最小限とし，水素製造システムにおける水蒸気改質 器の設計案による反応管本数 30 本のうち 1 本を模擬でき ること，すなわち，水素製造システムの $1 / 30$ とした。ま た，温度，圧力は水素製造システムと同条件で試験を行え る。試験装置の系統構成を Fig. 4 に示す。試験装置は, 蒸気発生器を用いた原子炉への熱外乱抑制に関する運転制 御技術の確立，水素製造システムの過渡举動の把握等に関 する各種試験を実施することを目的として，ヘリウムガス 循環ループにより 2 次ヘリウムガス采を模擬し，水素製 造設備の主要系統構成を水素製造システムと同様とした。

\section{2. 化学反応停止試験の概要}

水素製造設備に打いて化学反応停止という水蒸気改質器 の完全負荷啔失が生じた場合に打いても，2次へリウムガ ス除熱量を維持するための蒸気発生器を用いた冷却システ 么の実証㧍よび運転手順を確立するため，定格条件(水蒸 


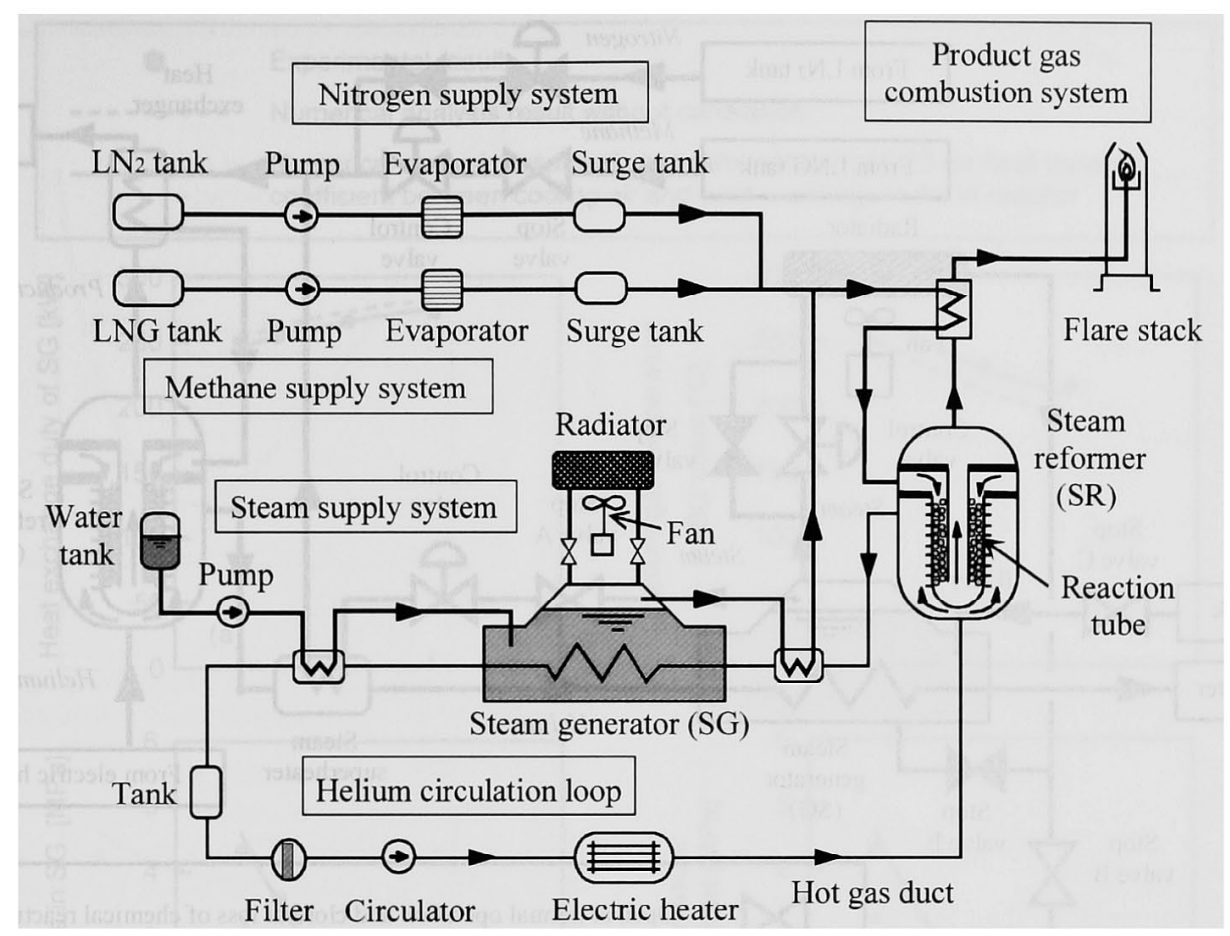

Fig. 4 Schematic flow diagram of mock-up test facility of hydrogen production system by steam reforming coupling with HTTR

気改質器入口のヘリウムガス流量 $0.091 \mathrm{~kg} / \mathrm{s}$, 温度 880.0 ${ }^{\circ} \mathrm{C}$, 水蒸気改質器入口の原料ガス流量 $0.012 \mathrm{~kg} / \mathrm{s}$, 温度 $450.0^{\circ} \mathrm{C}$ ) で水素製造中に原料ガス供給を遮断して水蒸気改 質反応を瞬時に停止させ, 蒸気発生器と放熱器のみによる ヘリウムガスの冷却を行う試験(以下，「化学反応停止試 験」と呼ぶ)を行った。化学反応停止時は，水素製造設備 で除熱すべき 2 次へリウムガスの熱量は通常運転時に対 して 2 倍以上となるため, 蒸気発生器での蒸気生成量が 2 倍以上となり, 給水量も通常運転時の 2 倍以上が必要と なる。このため，化学反応停止時には，蒸気発生器で生成 した蒸気を蒸気発生器上部に設置した放熱器で朎却し，凝 縮水を蒸気発生器へと戻す閉サイクルを形成し, 蒸気発生 器への給水制御を不要とする方法を提案している。試験装 置の蒸気発生器むわりの系統図を Fig. 5 に示す。システ ムの切り替え手順は以下の通りである。

（1）化学反応停止後, 蒸気過熱器および水蒸気改質器へ の蒸気供給停止(Valve A を閉)

（2）放熱器加らの凝縮水系外放出の停止 (Valve B を閉)

(3) 蒸気発生器への給水停止 (Valve C を閉)

(4) 放熱器への蒸気量を増加 (Valve D を開)

(5) 蒸気発生器と放熱器での蒸気/凝縮木の自然循環開 始(Valve E 孝開)

\section{3. 試験結果と解析結果の比較}

\section{（1）蒸気発生器一放熱器モデル}

本解析モデルの中で特に留意すべき機器として, 蒸気発 生器および放熱器が挙げられる。そのため, Fig. 3 で示し
た蒸気発生器一放熱器の解析モデルについて, 試験結果と 解析結果の比較を行った。

\section{(a) 定常時}

定常時の試験結果と解析結果の比較として, Fig. 6 に 化学反応停止後の蒸気発生器-放熱器間の蒸気/凝縮水の自 然循環時に，放熱器入口空気流量をパラメータとした場合 の蒸気発生器熱交換量, 蒸気発生器圧力, 蒸気発生器液相 温度, 蒸気発生器出口ヘリウムガス温度, 放熱器入口圧力 および放熱器出口蒸気/凝縮水温度の試験結果および解析 結果(破線)の関係, Fig. 7 に蒸気発生器入口ヘリウムガ ス温度をパラメータとした場合の蒸気発生器熱交換量, 蒸 気発生器圧力, 蒸気発生器液相温度, 蒸気発生器出口へリ ウムガス温度, 放熱器入口圧力および放熱器出口蒸気/凝 縮水温度の試験結果および解析結果(破線)の関俰を示す。 試験結果では, 放熱器入口空気流量の増加に伴い, 蒸気発 生器での熱交換量が増加し, それに伴い, 蒸気発生器圧 力, 蒸気発生器での熱交換量, 蒸気発生器液相温度, 蒸気 発生器出口ヘリウムガス温度, 放熱器入口圧力および放熱 器出口蒸気/凝縮水温度は下降する。蒸気発生器抢よび放 熱器での圧力扔よび温度の解析結果は試験結果の傾向をほ ぼ模擬できている。しかし, 蒸気発生器の熱交換量の解析 結果は試験結果より若干大きい。また，圧力および温度の 解析結果は試験結果よりも小さくなっている。このことか ら, 解析モデルでは試験結果に比べ放熱器で過冷却となっ ていることがわかった。空気側熱伝達の設計式である Jamesonの式はフィン付き管群を用いた実験の結果を整 理したものである。フィン付伝熱管群の熱伝達特性につい 


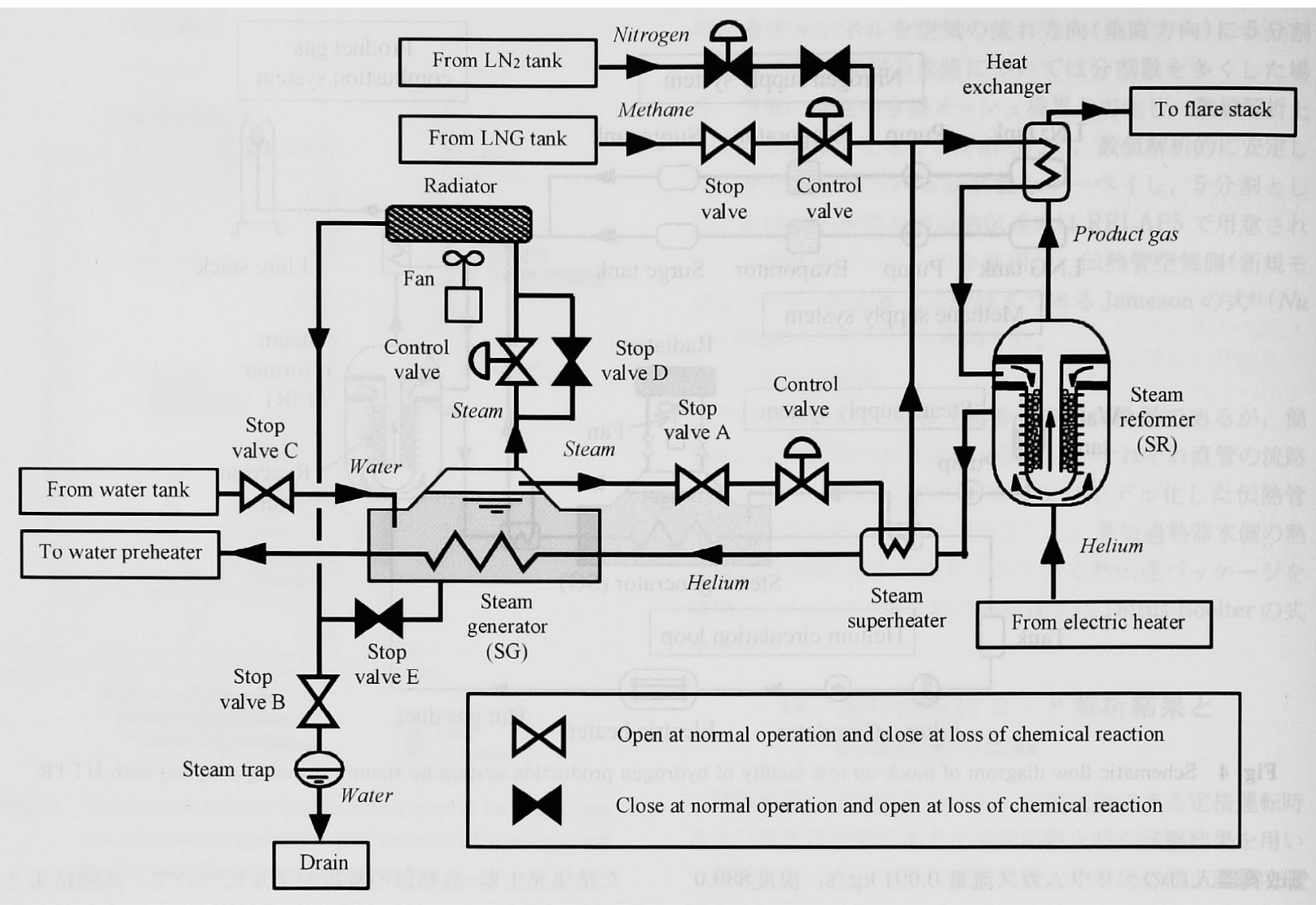

Fig. 5 Detailed flow diagram of the cooling system for helium with the steam generator and the radiator of the mock-up test facility

ては，後列に行くに従い前方の管で作られた乱れの影響を 受けるため，管群の列数が少なくなるほど，熱伝達係数が 减少するという結果が得られている10)。Jamesonの試験 では 8 列の管群を採用しているが, 試験装置の放熱器の 伝熱管は 3 列の管群であるので, (13)式で示すように, 空気側の熱伝達㐿数の相関係数 $K$ を用い, 評価を行った。

$$
N u=K \cdot 0.092 \operatorname{Re}^{0.723} \mathrm{Pr}^{0.333}
$$

ここでは, 蒸気発生器から放熱器間で蒸気, 凝縮水が安定 に自然循環している状態において, 放熱器空気風量および 蒸気発生器入口へリウムガス温度をパラメータとし, 蒸気 発生器熱交換量, 蒸気発生器圧力, 蒸気発生器液相温度, 蒸気発生器出口へリウムガス温度, 放熱器入口任力および 放熱器出口蒸気/凝縮水温度を対象として, 試験結果と解 析結果の相対䛊差 $(=\{($ 試験結果 $)-($ 解析結果 $)\} /($ 試験結 果))を算出した。その結果, Fig. 8 に示すように, 相関 係数が0.75の時において，相対誤差の 2 乗和が最小とな り, 試験結果と解析結果が最も一致することがわかった。 本結果から求めた放熱器空気側熱伝達式の実験による評価 式を(14)式に示す。

$$
N u=0.069 R e^{0.723} \operatorname{Pr}^{0.333}
$$

この場合の各条件における解析結果 (実線)を Fig. 6 およ びFig. 7 に示す。設計式を用いた場合の相対誤差が $12 \%$ であったのに対し，実験による評価式を使用した相対誤差
は 4\%まで減少し，解析精度を向上させることができた。

(b) 非定常時 (反応停止時)

蒸気発生器一放熱器解析モデルについて非定常計算を行 った。解析の境界条件は, 蒸気発生器入口のヘリウムガス 流量および温度, 蒸気発生器出口ヘリウムガス圧力, 放熱 器入口空気流量, 温度および圧力であり, 化学反応亭止試 験時の試験結果を用いた。解析結果と試験結果の比較を Fig. 9 に示す。試験結果では，水蒸気改質器での化学反 応停止後, 蒸気発生器入口ヘリウムガス温度が上昇するた め, 蒸気発生器の蒸気製造量が増加し, 蒸気発生器圧力が 上昇した。その後, 放熱器入口遮断弁の開操作により蒸気 発生器での蒸気が放熱器へと流入するため, 蒸気発生器で の圧力はいったん下降するが, 蒸気発生器入口へリウムガ ス温度は上昇を続けるため, 蒸気発生器圧力は上昇に転じ た。その後, 放熱器出口遮断弁の開操作により蒸気発生 器一放熱器での蒸気/凝縮水の自然循環が始まるため蒸気発 生器圧力は下降し, 蒸気発生器と放熱器での交換熱量がハ ランスする点にて静定した。蒝気発生器出ロヘリウムガス 温度は蒸気発生器内の保有水温度, つまり蒸気発生器圧力 の影響を受けるため, 蒸気発生器圧力と同様な变動傾向を 示した。また, 蒸気発生器から放熱器への蒸気流量の試験 結果は放熱器の出入口の遮断弁の開操作によりそれぞれ, ピークが発生するが, 蒸気/凝縮水の自然循環状態では循 

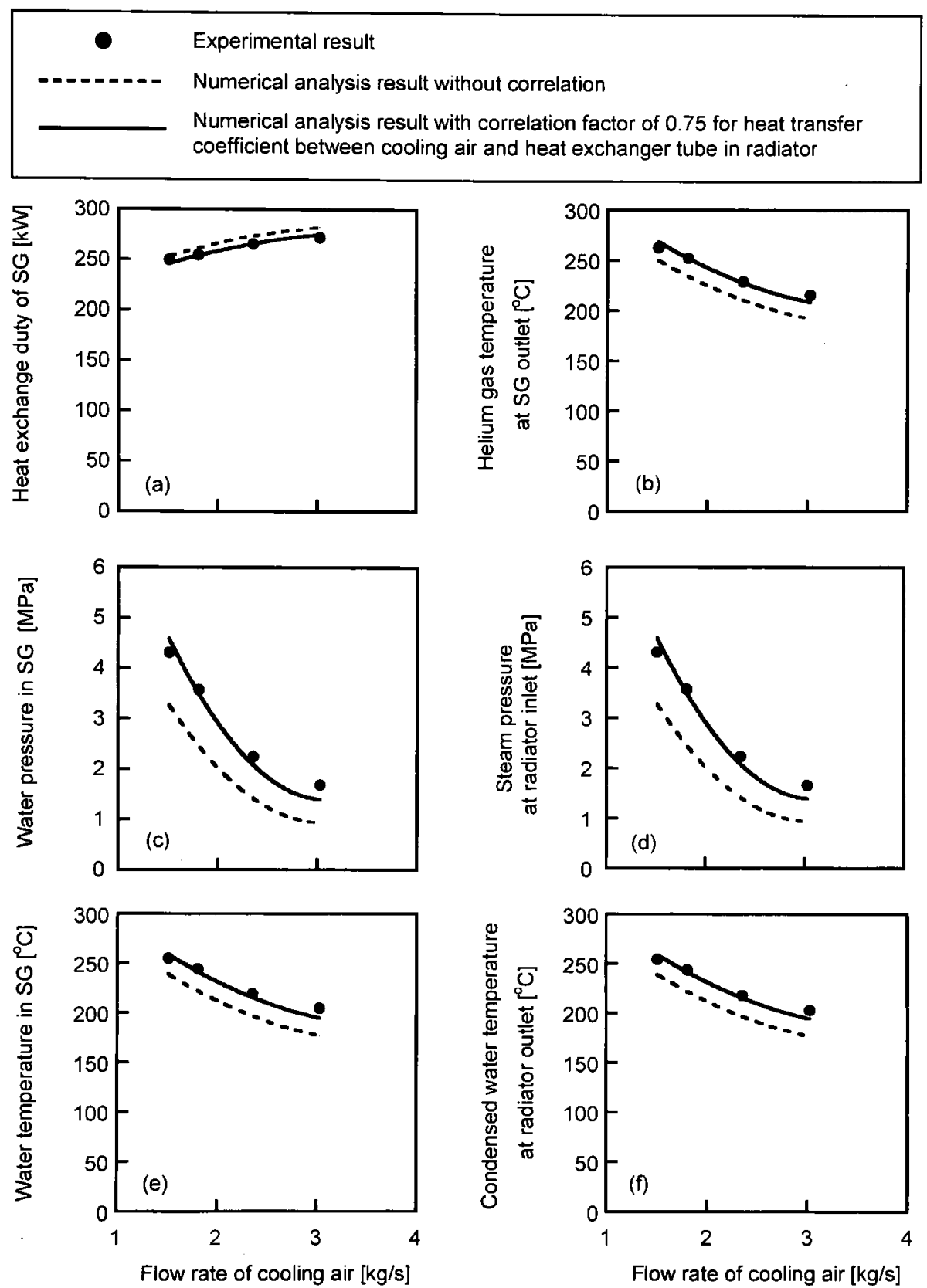

Fig. 6 Relationship between the flow rate of the cooling air and the experimental and the numerical analysis results of the heat exchange duty of steam generator, the helium gas temperature at steam generator outlet, the water pressure in steam generator, the steam pressure at the radiator inlet, the water temperature in steam generator and the condensed water temperature at the radiator outlet

環流量は安定した。

本試験結果に対して解析結果は, 試験結果である化学反 応停止時における蒸気発生器出ロヘリウムガス温度, 蒸気 発生器圧力抢上び放熱器入口蒸気/凝縮水流量の变動傾向 をよく模擬できることを確認した。また，蒸気発生器へリ ウムガス出口温度および蒸気発生器圧力の試験開始前の定 常値に対する試験結果の変動幅はそれぞれ， $-1.2 \sim+2.0$ ${ }^{\circ} \mathrm{C}, 4.26 \sim 4.48 \mathrm{MPa}$ に対し, 解析結果は $+8.4^{\circ} \mathrm{C}, 4.35 \sim$ $4.83 \mathrm{MPa}$ であった。このことから, 蒸気発生器出口へリ
ウムガス温度および蒸気発生器圧力の試駼結果と解析結果 はほぼ一致することを確認した。

\section{(2) 全体系モデル}

試軻装置全体系の解析モデルについて，定常時および非 定常時の計算を試験装置の試験結果と解析結果の比較を行 った。試験装置全体の解析モデル図を Fig. 10 に示す。な お, 解析モデル中の水蒸気改質器および蒸気発生器まわり については, Fig. 2 および Fig. 4 の解析モデルを使用し ている。 

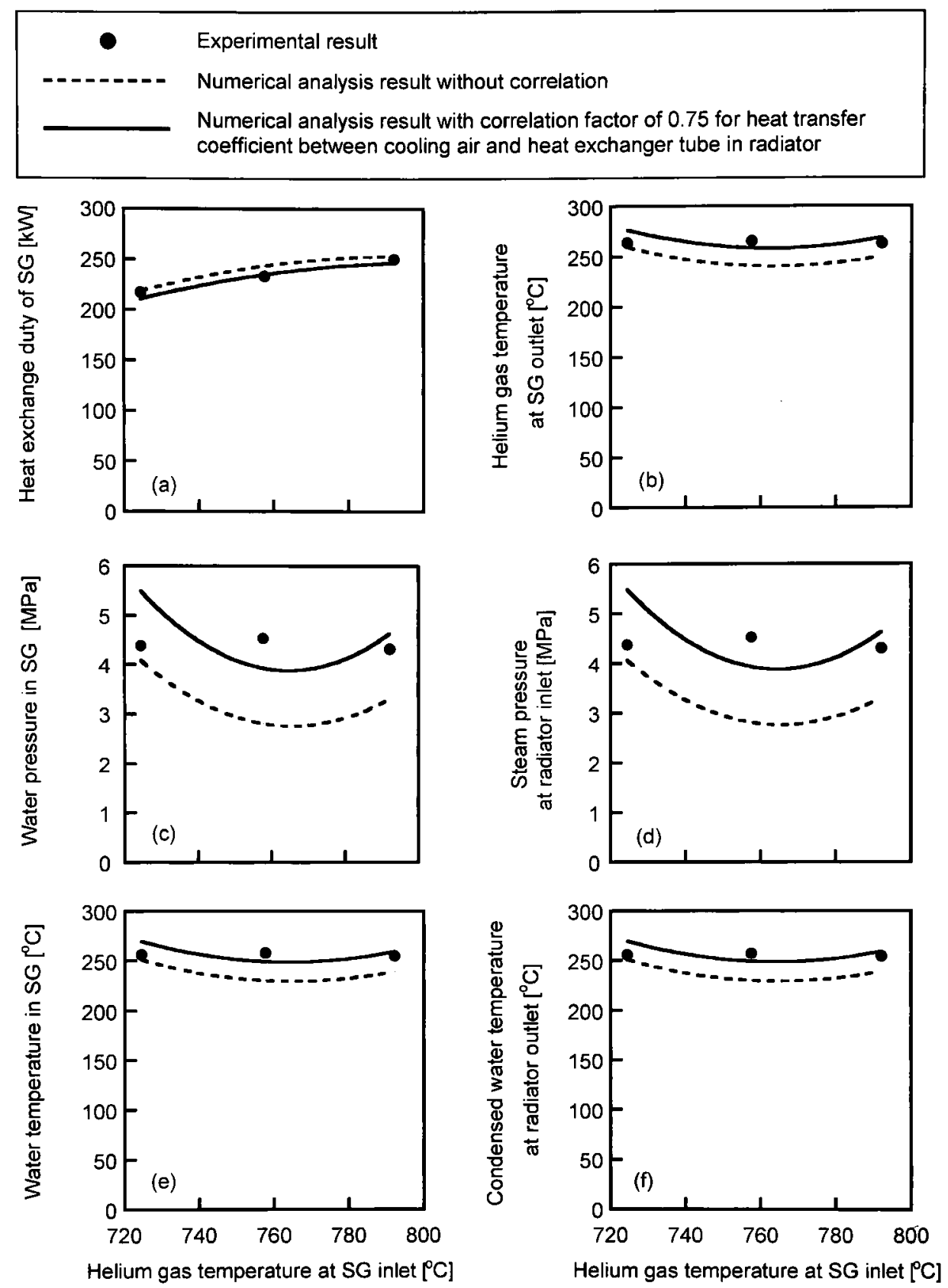

Fig. 7 Relationship between the helium gas temperature at steam generator inlet and the experimental and the numerical analysis results of the heat exchange duty of steam generator, the helium gas temperature at steam generator outlet, the water pressure in steam generator, the steam pressure at the radiator inlet, the water temperature in steam generator and the condensed water temperature at the radiator outlet

(a) 定常時

定常解析として，定格条件を対象とした解析を行い，試 験結果上比較を行った。解析の境界条件は, 水蒸気改質器 入口のヘリウムガス流量, 温度 $\left(0.091 \mathrm{~kg} / \mathrm{s}, 880.0^{\circ} \mathrm{C}\right)$, 蒸 気発生器出口ヘリウムガス圧力 $4.03 \mathrm{MPa}$, 原料ガス加熱 器入口の原料ガス流量, 温度 $\left(0.012 \mathrm{~kg} / \mathrm{s}, 12.0^{\circ} \mathrm{C}\right)$, 原料 ガス加熱器出口生成ガス圧力 $4.19 \mathrm{MPa}$ である。試験装置 の各温度計測点における解析結果と試験結果の比較を Fig. 10 中に示す。へリウムガス，プロセスガスおよび生
成ガス温度の解析結果は試験結果とほほ一致していること が確認できる。例えば，水蒸気改質器出口および蒸気発生 器出口におけるへリウムガス温度の試験結果 $632.4^{\circ} \mathrm{C}$ 抢

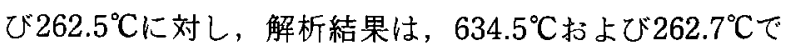
あった。

(b) 非定常時 (反応停止時)

解析の境界条件は, 水蒸気改質器入口のへリウムガス流 量および温度, 蒸気発生器出口ヘリウムガス圧力, 原料カ ス加熱器入口の原料ガス流量抢よび温度, 原料ガス加熱器 


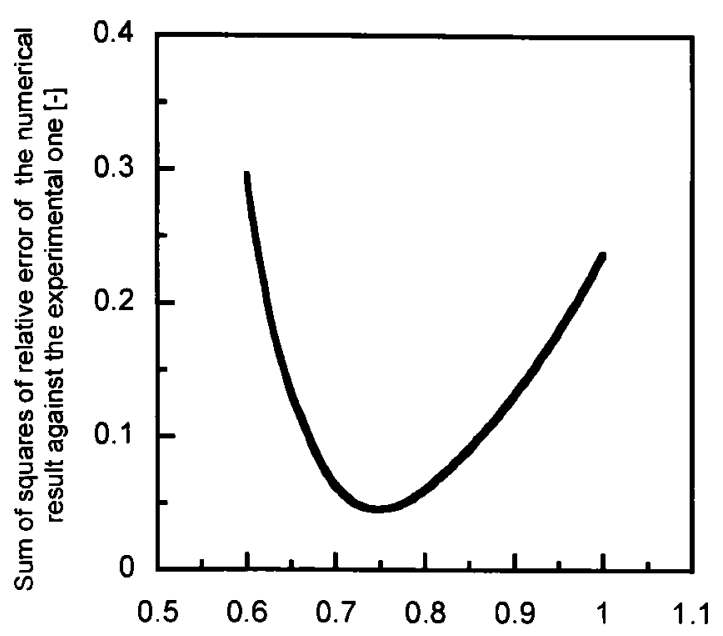

Correlation coefficient for heat transfer coefficient between cooling air and heat exhanger tube in radiator, $\mathrm{K}[-]$

Fig. 8 Relationship between the sum of squares of the relative error of the numerical analysis results against the experimental results and correlation coefficient for the heat transfer coefficient between the cooling air and the heat exchanger tube in the radiator

出口生成ガス圧力であり，化学反応停止試験時の試験結果 を用いた。解析結果と試験結果の比較を Fig. 11 に示す。 水蒸気改質器出口ヘリウムガス温度の試験結果は, 原料力 又遮断後約 1.2 時間後に最大值まで上昇し，その啳緩やか に変化し静定した。これに対し，解析結果は同様な変動傾 向を示した。また, 蒸気発生器入口ヘリウムガス温度, 蒸 気発生器出ロヘリウムガス温度および蒸気発生器圧力の解 析結果の変動傾向は蒸気発生器一放熱器単体モデルでの解 析結果と同樣の変動傾向を示し, 試験結果とほぼ一致し た。また，原子炉への熱外乱抑制の観点から特に着目すべ き蒸気発生器出ロヘリウムガス温度について, 試験開始後 (化学反応停止後) $2,160 \mathrm{~s}$ において, 解析結果は試験結果

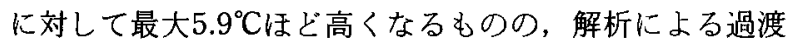
事象の挙動は試験結果を精度良く模擬できており，本解析 モデルが妥当であると判断できる。

\section{4. 水素製造システムの解析}

Fig. 1 亿示す，水素製造システムでは水蒸気改質器での 化学反応停止時が最大の過渡変動となることから，このと きの原子炬への戻りヘリウムガス温度の評価が重要であ る。水素製造システムの解析では, 化学反応停止時の原子 炬への戻りヘリウムガス温度が所定の值に制御できること の確認を目的として, 定常解析および非定常解析を行っ た。水素製造システムの解析モデル図を Fig. 12 に示す。 なお, 全系モデル中の蒸気発生器および水蒸気改質器の解 析モデルは Fig. 2 および Fig. 3 を用いている。

\section{(1) 定常解析}

定常解析として，定格条件を対象とした解析を行い，熱
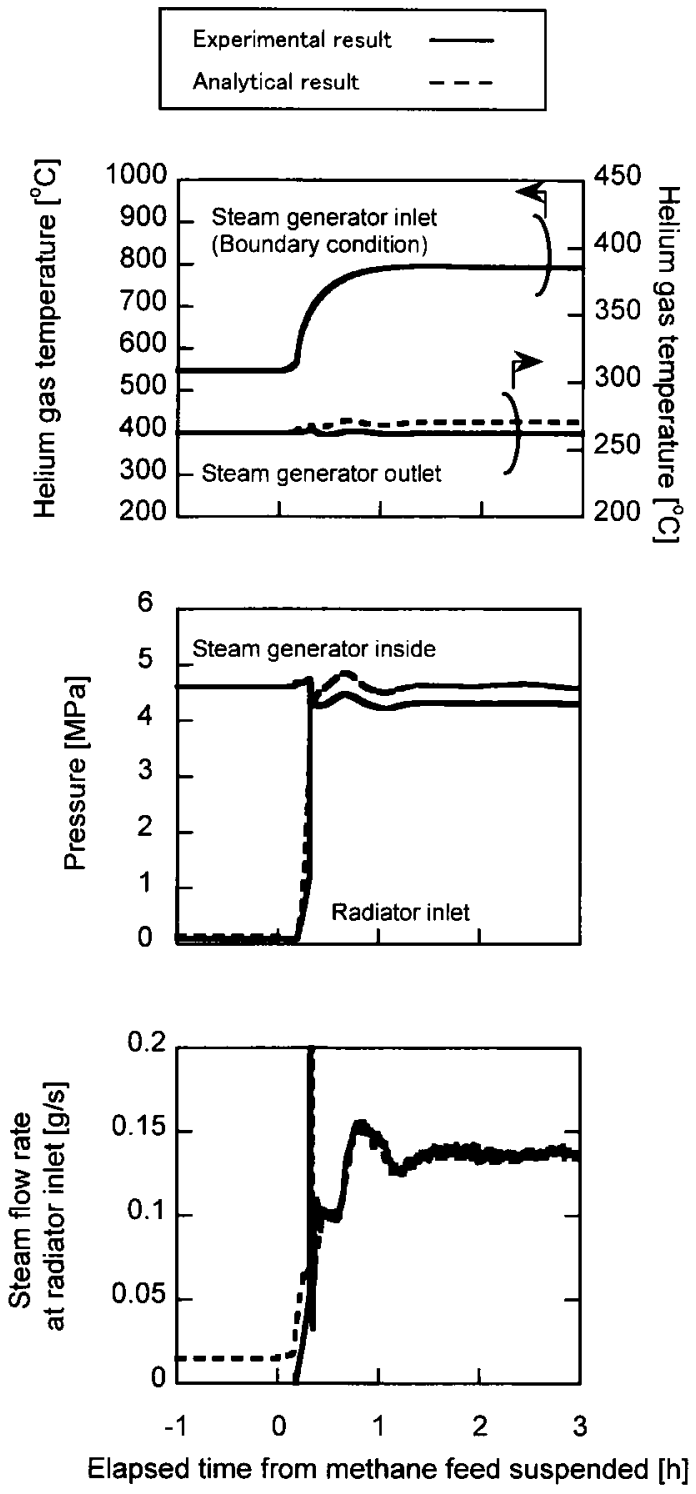

Fig. 9 Comparison between experimental and numerical analysis results of helium gas temperature at the outlet of steam generator, pressure of steam generator and radiator and steam flow rate at the inlet of radiator in the mock-up test facility at loss of chemical reaction test

物質収支を確認した。解析の境界条件は原料ガス加熱器入 ロプロセスガス流量および温度, 原料ガス加熱器出ロプロ セスガス圧力, 蒸気発生器入口給水温度, 放熱器入口空気 温度, 放熱器出口空気圧力, 中間熱交換器入口 1 次へリ ウムガス温度, 流量抢よび圧力掞よびヘリウムガス冷却器 入口冷却水流量および温度であり，それぞれ，Table 1 に 示す水素製造システムの設計值を用いた。解析結果を Fig. 12 中に示す。定常時の解析を行った結果, 温度, 圧 力および流量の計算結果は静定することを確認した。

(2) 非定常解析

非定常解析として水素製造システムの化学反応停止時の 解析を行った。解析の境界条件は定常時と同しであり, 水 


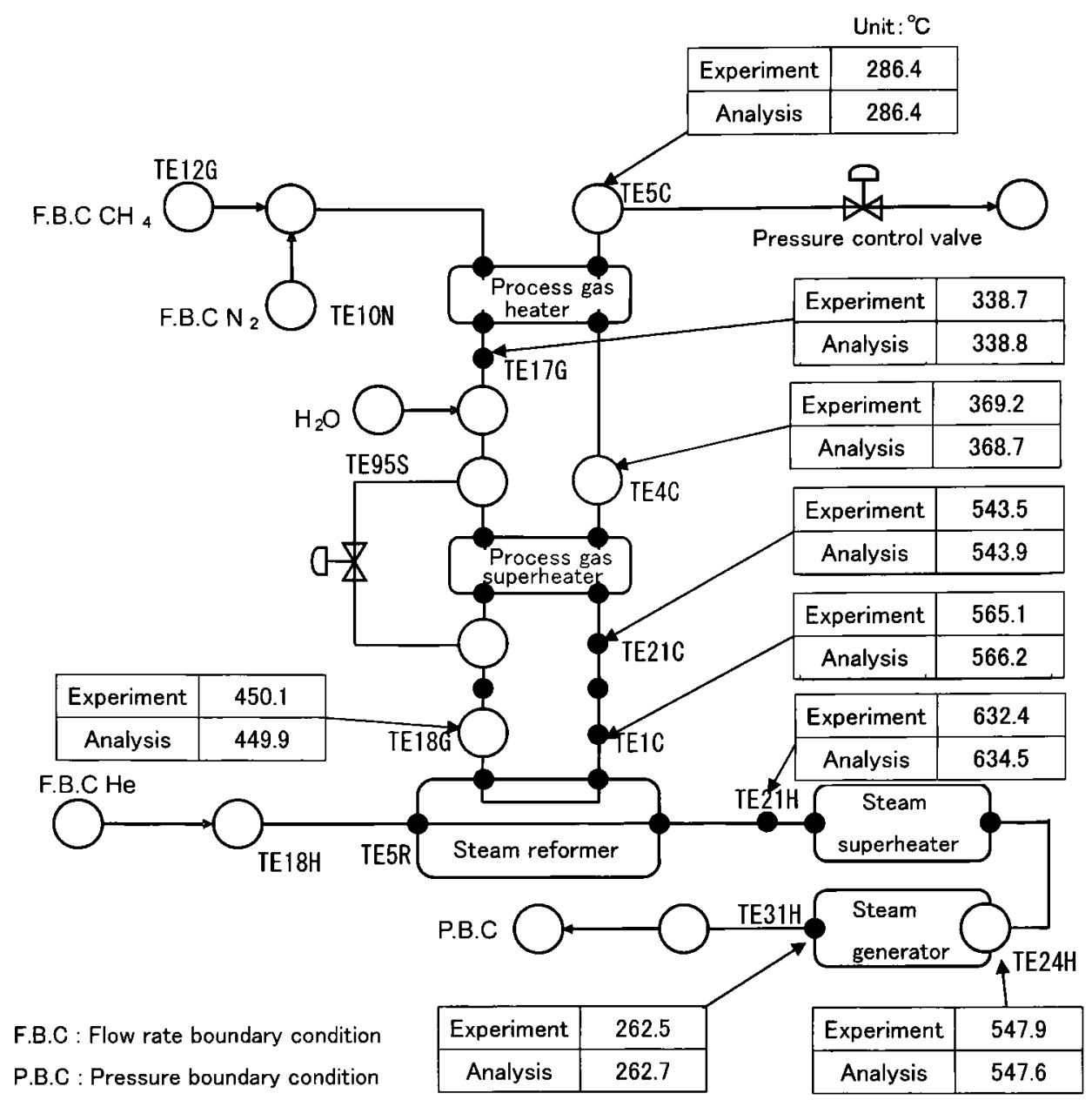

Fig. 10 Comparison between the experimental and the numerical analysis results of test facility at rated condition of hydrogen production

素製造システムの設計条件を用いた。Fig. 13 に 2 次へリ ウムガス系の温度の解析結果を示す。水蒸気改質器での化 学反応停止に伴い, 水蒸気改質器での除熱能力が喪失し

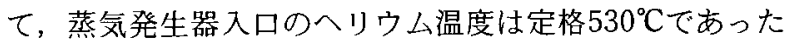
ものが約 $850^{\circ} \mathrm{C}$ ま昇するが，蒸気発生器の保有水によ りこの温度変動が緩和され，蒸気発生器出口ヘリウムガス 温度の変動は小さくなるため，原子师側への戻りへリウム ガス温度は所定の值に制御可能であることを確認した。本 結果から，水素製造システムの全体系の解析モデルについ て，定常時抢よび非定常時の計算を行い，本解析コードを 用いて原子炬への熱過渡を予測することができることを確 認した。

\section{V. 結 言}

水素製造システムの過渡挙動を把握するために動特性解 析コード開発を行った。以下に本研究の成果を示す。

（1）試験装置の試験結果を用いて解析結果との比較を行 った結果，原子炉への熱外乱抑制の観点から特に着目 すべき蒸気発生器出口ヘリウムガス温度について, 解
析結果の変動傾向は試験結果とほほ一致しておうり，化 学反応停止時の試験結果での定常值 $262.5^{\circ} \mathrm{C}$, 温度変 動幅 $-1.2 \sim+2.0^{\circ} \mathrm{C}$ に対して試験結果と解析結果の温

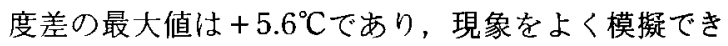
ることを確認できた。

（2）HTTRに接続する水蒸気改啠法による水素製造シ ステムの動特性を予測できるコードを開発し，水素製 造システムの過渡挙動を予測できることを確認した。

本成果は，高温ガス炉と水分解熱化学法 IS プロセス ${ }^{11}$ による水素製造設備の接続技術の開発に寄与するものであ る。

本研究は, 電源開発促進対策特別会計法に基づく文部科 学省加の受託事業として, 日本原子力研究開発機構(旧 日本原子力研究所) が実施した平成 9 年度, 12 年度, 13 年 度，14年度，15年度，16年度，17年度「核熱利用システ 么技術開発」の成果です。

本試験および評価に多大なるご協力を頂いた新型炉技術 開発珠の岸田雅子氏, 三菱重工業珠の森崎徳浩氏, 珠日立 

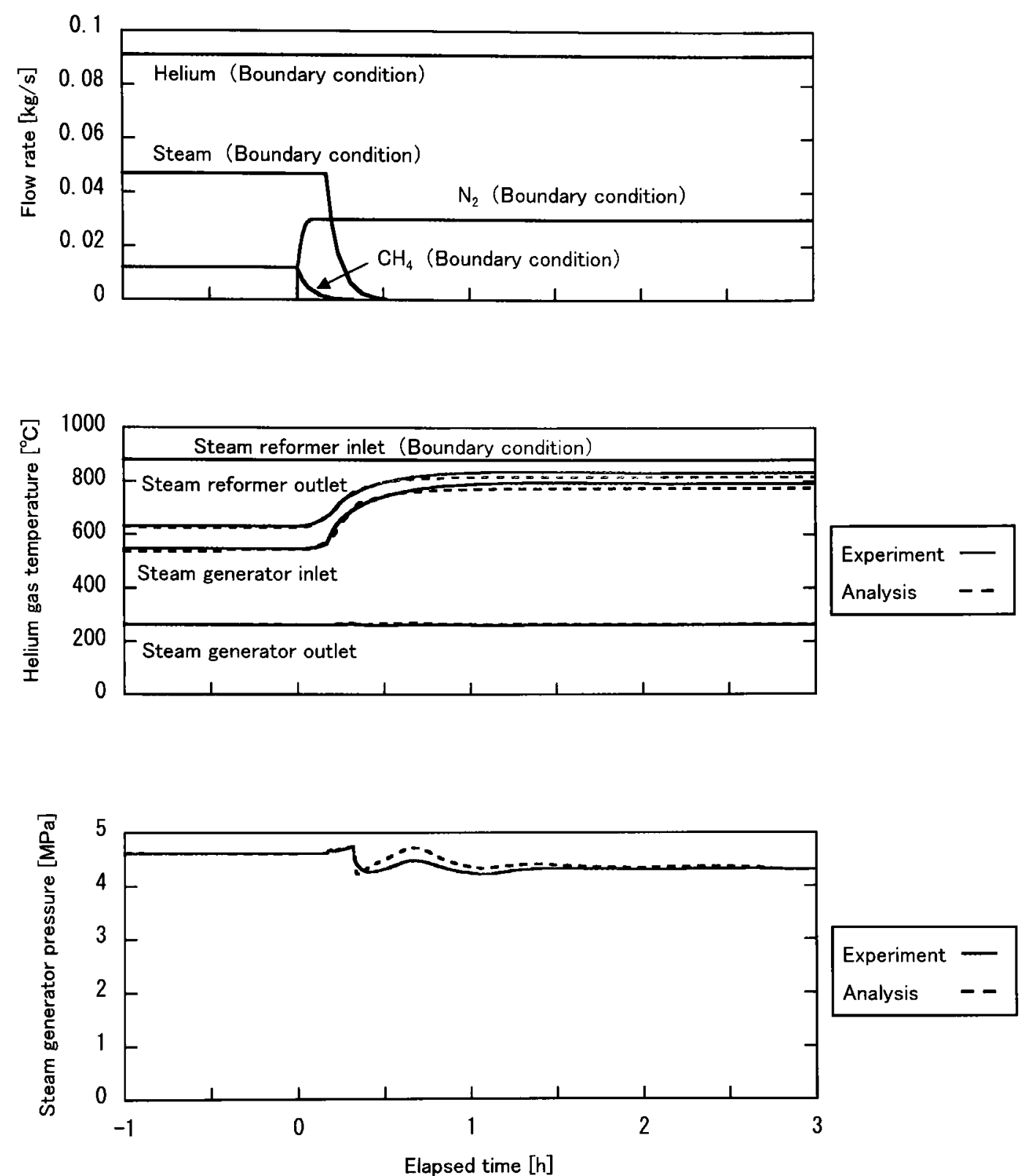

Fig. 11 Comparison between the experimental and the numerical results of helium gas temperature at the inlet and outlet of the steam generator, outlet of the steam reformer and steam generator pressure in the mock-up test facility at loss of chemical reaction test

製作所の前田幸政氏に感謝いたします。また，本研究の遂 行に当たり，有益なご助言を頂いた日本原子力研究開発機 構原子力基礎工学研究部門核熱応用工学ユニット長の小川 益郎氏に感謝いたします。

\section{一参考文献一}

1) 宮本喜晟, 他, 水素エネルギー研究の現状と高温ガス炉水素 製造システムの将来展望, JAERI-Review 2001-006, (2001).

2) S. Fujikawa, et al., "Achievement of reactor-outlet coolant temperature of $950^{\circ} \mathrm{C}$ in HTTR," J. Nucl. Sci. Technol., 41[12], 1245-1254 (2004).

3）前田幸政，他，HTTR 水素製造システム動特性解析コード
N-HYPAC の開発 (受託研究), JAERI-Tech 2005-001, Japan Atomic Energy Research Institute (2005).

4) H. Ohashi, et al., "Performance test results of mock-up test facility of HTTR hydrogen production system," J. Nucl. Sci. Technol., 41[3], 385-392 (2004).

5) 羽田一彦, 他, 高温ガス炉一水素製造システムの汎用性を有 する安定な制御設計概念，日本原子力学会誌， 38,834 (1996).

6) V. H. Ransom, et al, RELAP5/MOD2 Code Manual, NUREG/CR-4312, EGG-2796, Idaho National Engineering Laboratory, (1985).

7) J. H. Wiegand, "Discussion of paper by McMillen and Larson," Trans. AIchE, 41, 147 (1945).

8) S. L. Jameson, et al., "Tube spacing in finned-tube banks," 


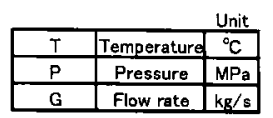

B.C: Boundary Condition
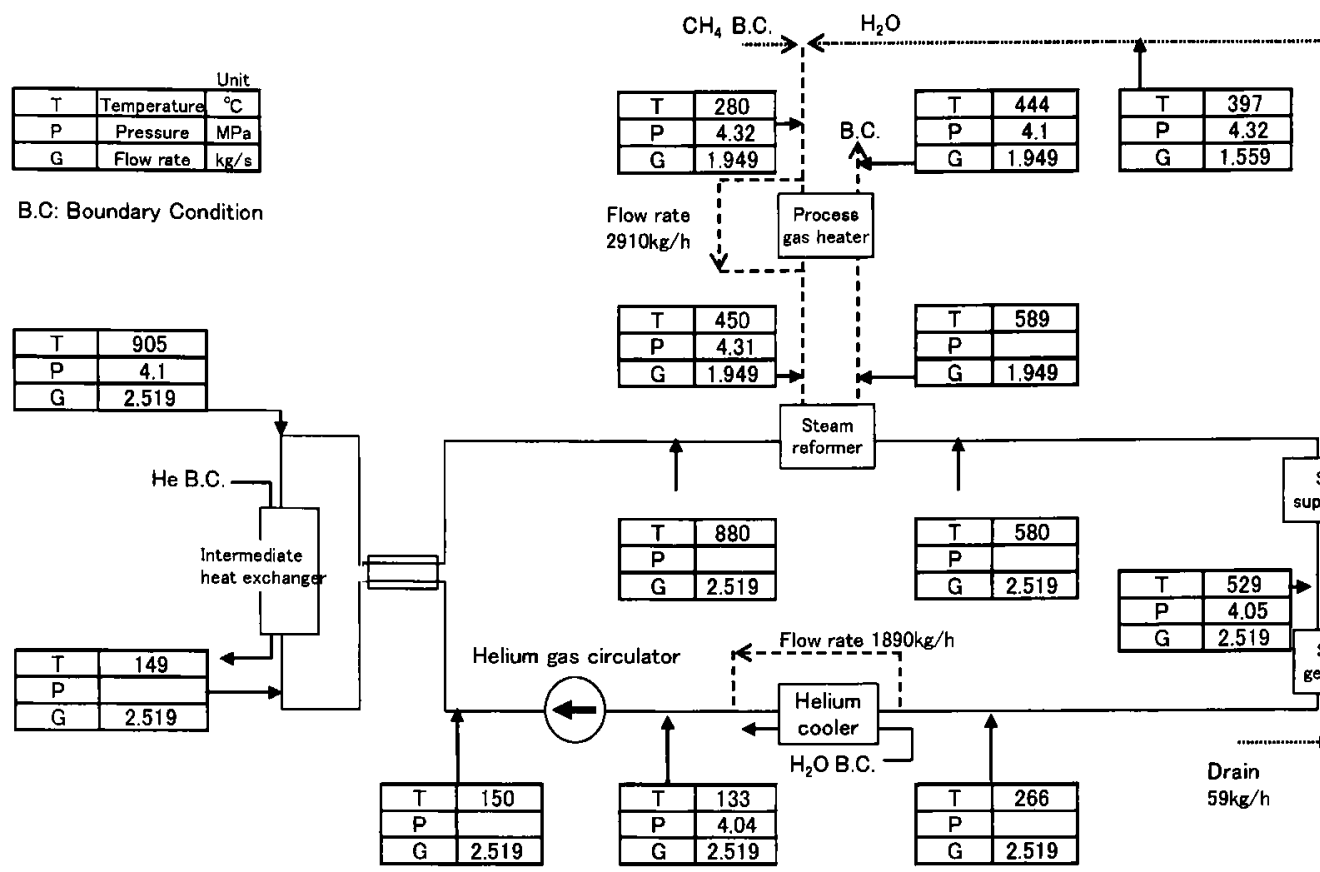

reformer
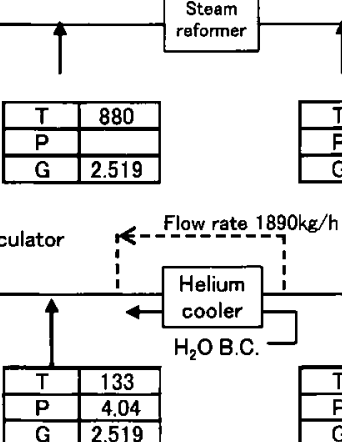

Flow rate $1890 \mathrm{~kg} / \mathrm{h}$

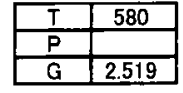

Fig. 12 The numerical analysis results of hydrogen production system at rated condition of hydrogen production

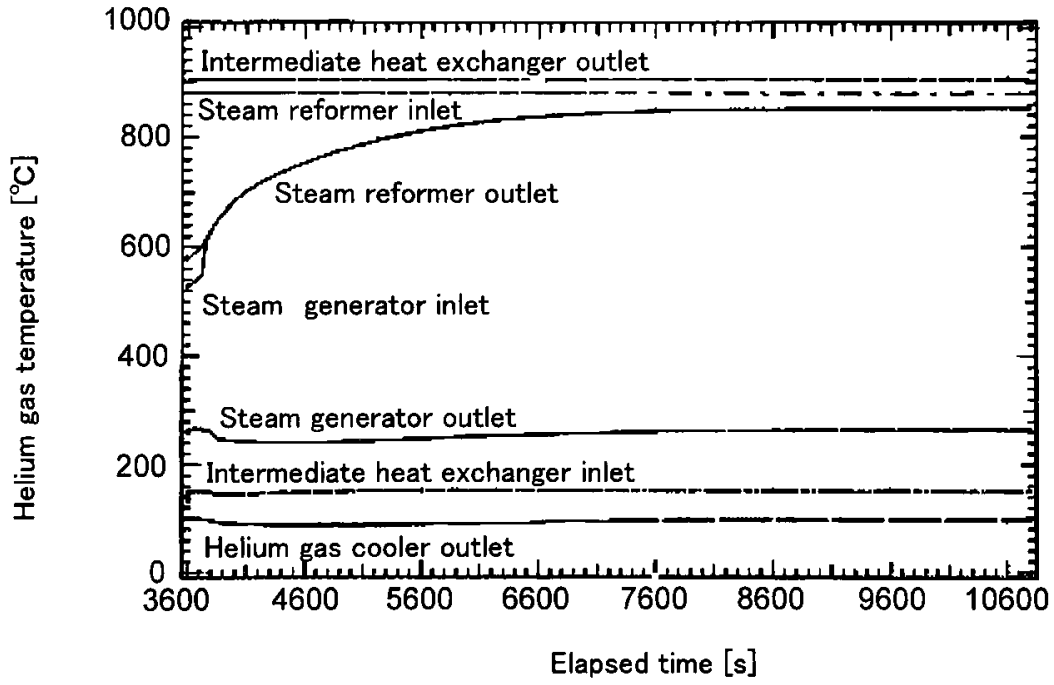

Fig. 13 Numerical analysis results of helium gas temperature at the inlet and outlet of the intermediate heat exchanger, steam reformer, steam generator, and outlet of the helium cooler in the hydrogen production system at loss of chemical reaction test

Trans. A.S.M.E., 67, 633-642 (1945)

9）稲垣嘉之，他，“高温ガス炬 HTTRを用いた水素製造システ 厶の灯外実証試験計画, ”日本原子力学会誌, 41[3], 250 (1999).

10) E. M. Sparrow, et al., "Heat transfer and pressure drop results for one- and two-row arrays of finned tubes," Int. $J$ Heat Mass Transfer, 28[12], 2247-2259 (1985).

11) S. Kubo, et al., "A demonstration study on a closed-cycle hydrogen production by thermochemical water-spliting IS process," Nucl. Eng. Des., 233, 347-354 (2004). 